\title{
Kinetic parameters of lipid oxidation in third generation (3G) snacks and its influence on shelf-life
}

\author{
Judith JAIMEZ-ORDAZ ${ }^{1}$, Jesús Guadalupe PÉREZ-FLORES ${ }^{1}$, Araceli CASTAÑEDA-OVANDO ${ }^{1}$, \\ Luis Guillermo GONZÁLEZ-OLIVARES ${ }^{1}$, Javier AÑORVE-MORGA ${ }^{1}$, Elizabeth CONTRERAS-LÓPEZ ${ }^{1 \star}$
}

\begin{abstract}
In food systems, lipid oxidation is one of the most important factors affecting food quality, nutrition, safety, color and consumer acceptance. The objective of this study was to determine the kinetic parameters of lipid oxidation and its influence in the shelf life of third generation (3G) snacks stored in three types of packaging (polyethylene, polypropylene + Kraft paper, and polyethylene + polypropylene) at $25^{\circ} \mathrm{C}$ and $40{ }^{\circ} \mathrm{C}$. The peroxide value was the quality parameter selected and monitored for a 60 day period using a spectrophotometric technique. Based on the Arrhenius equation and activated complex theory, reaction rate constants $(\mathrm{k})$, activation energies $\left(\mathrm{E}_{\mathrm{a}}\right), \mathrm{Q}_{10}$ factors, activation enthalpies $\left(\Delta \mathrm{H}^{\ddagger}\right)$, and activation entropies $\left(\Delta \mathrm{S}^{\ddagger}\right)$ for oxidative stability in $3 \mathrm{G}$ snacks were calculated. Results showed that oxidation phenomena can occur in the $3 \mathrm{G}$ snacks and affect its shelf-life. Packaging C (polyethylene + polypropylene) was the most appropriate for the storage of this kind of product. Finally, the shelf life of the analyzed pellets was longer than one year at $25^{\circ} \mathrm{C}$ and it may be extended with the appropriate mix of packaging materials.
\end{abstract}

Keywords: shelf life, $3 \mathrm{G}$ snacks, peroxide value, packaging materials, kinetic analysis.

Practical Application: Results of this study showed the most appropriate packaging material for $3 \mathrm{G}$ snacks.

\section{Introduction}

The International Food Information Service (IFIS) defines snack foods as: sweet or savory foods eaten to provide light sustenance in a quick and convenient format, eaten between or as an alternative to main meals. Popular types include sandwiches, cereal bars, and potato crisps also known as snacks (International Food Information Service, 2009). Snacks have been classified as first, second, and third generation according to the different elaboration techniques available and according to their evolution as time goes by (Huber \& Rokey, 1990; Huber, 2001). Third generation snacks (3G), pellets, or intermediate products, are obtained through extrusion or co-extrusion of a blend of cereals and starch (modified and non-modified) (Harper, 1989). The final product is obtained after expansion with hot air, microwaves, oil immersion, or infrared radiation (Harper, 1989; Huber \& Rokey, 1990; Maskan \& Altan, 2011). On the other hand, the shelf life of food products shelf life depends on: 1. - formulation and processing (intrinsic factors); 2. - environmental conditions during distribution and storage stages (extrinsic factors); and 3. - packaging properties (Robertson, 2012). In previous research it has been reported that pellets shelf life is affected mainly by two deterioration mechanisms: rancidity and loss of crispiness due to humidity absorption. Therefore, the importance of packaging in product preservation has been described (Bárcenas-Serrano et al., 2015; Pérez-Flores et al., 2017). Finally, the aim of this work was to analyze the changes in the peroxide value on pellets after storing them at different temperatures, with the purpose of estimating their shelf life and to evaluate the influence of packaging on the final product.

\section{Materials and methods}

\subsection{Samples and packaging}

A local Mexican snack manufacturing company provided the pellet samples and the test packaging materials as part of a research project. The composition of the samples cannot be given due to trade secrets, but the main ingredient was wheat flour. Three packaging materials were proposed by the company to be studied:(A) high density polyethylene (HDPE); (B) polypropylene covered with Kraft paper; and (C) HDPE with a polypropylene cover.

\subsection{Proximate analysis}

The proximate composition of pellets was determined according to the methods established by the AOAC (Association of Official Analytical Chemists, 1990) as follows: humidity (925.10), ash (923.03), ether extract (923.05), and crude fiber (962.09). Protein determination was done with the Dumas method (990.03) using a LECO FP-528 equipment. Soluble carbohydrates content was calculated by difference. 


\subsection{Microbiological analysis}

The microbiological quality of the pellets was performed according to techniques established in Mexican regulations: total coliform bacteria count, aerobic mesophilic bacteria count, and mold and yeast count, at the beginning and at the end of the study (Pérez-Flores et al., 2017).

\subsection{Shelf life estimation}

$3 \mathrm{G}$ snacks samples weighing $50 \mathrm{~g}$ were stored inside a LABLINE ${ }^{\circledR}$ stove for a 60 day period at $25^{\circ} \mathrm{C}$ and $40^{\circ} \mathrm{C}$, the latter being considered the extreme condition. Samples were placed inside the three different types of test packaging (A, B, and C). Peroxide value (PV) was selected as the critical quality parameter.

\section{Peroxide Value (PV) measurement}

Peroxide value (PV) was analyzed following method adapted from Hornero et al. (2001). A one gram pellet sample was weighed and transferred to a test tube where $9 \mathrm{~mL}$ of $\mathrm{CH}_{3} \mathrm{COOH}: \mathrm{CHCl}_{3}(3: 2)$ mixture were added. After homogenization for a minute in a vortex, $100 \mu \mathrm{L}$ of a Fe (II) $\left(100 \mathrm{mg} \mathrm{L}^{-1}\right)$ solution were added and then homogenized again for another minute. Afterwards, the sample was put under centrifugation for $15 \mathrm{~min}$ at $2000 \mathrm{rpm}$ and the contents (with $\mathrm{Fe}$ (III)) were transferred to a $10 \mathrm{~mL}$ volumetric flask. A $100 \mu \mathrm{L}$ of SCN $\mathrm{S}^{-}\left(100 \mathrm{mg} \mathrm{L}^{-1}\right.$, from KSCN) were added and then gauged with the $\mathrm{CH}_{3} \mathrm{COOH}: \mathrm{CHCl}_{3}(3: 2)$ mixture, allowing them to react for 13 minutes in order to produce the red color complex $\left(\mathrm{Fe}(\mathrm{SCN})^{2+}\right)$ which was later analyzed by $\mathrm{UV}$ - vis at $470 \mathrm{~nm}$ with a correction wave of $670 \mathrm{~nm}$. Each one of the samples was analyzed in triplicate. Determinations were done every 7 days and the results were reported in $\mathrm{mmol}$ peroxide $\mathrm{kg}^{-1}$ for each sample.

\section{Kinetic data analysis}

Kinetic data were analyzed following a general mathematical model or "logistic equation", which describe the autoxidative process of lipids in food systems (Özilgen \& Özilgen, 1990). The model is described in Equation 1.

$\frac{d C}{d t}=k C\left[1-\frac{C}{C_{\max }}\right]$

Where $C$ is concentration of the total oxidation products in function of time $(t), C_{\max }$ is the maximum attainable value of parameter $C$ at the end of the lipid oxidation process, $k$ is the reaction rate constant. The integration of Equation 1 gives Equation 2, the oxidation kinetics of lipids is expressed by the equation of the autocatalytic type in terms of the fraction of unoxidized lipids, $1-X$, where $X$ is calculated according to Equation 3 .

$k t=\ln \left(1-\frac{C}{C_{\max }}\right)+\ln \left(\frac{X}{1-X}\right)$

$X=C / C_{\max }$
The effect of temperature on the rate of lipid oxidation in $3 \mathrm{G}$ snacks was illustrated by means of the Arrhenius equation, Equation 4 (Labuza, 1984).

$\ln (k)=\ln A-\left(\frac{E_{a}}{R T}\right)$

Thus, the $\mathrm{Q}_{10}$ will depend on the value of the activation energy, Equation 5 (Waletzko \& Labuza, 1976).

$\ln Q_{10}=\frac{E_{a}}{R}\left(\frac{10}{T(T+10)}\right)$

Enthalpy $\left(\Delta \mathrm{H}^{\ddagger}\right)$ and entropy $\left(\Delta \mathrm{S}^{\ddagger}\right)$ of activation were determined via the equation derived from activated complex theory, Equation 6 (Tan et al., 2001b).

$\ln \frac{k}{T}=\frac{-\Delta H^{\ddagger}}{R} \frac{1}{T}+\ln \frac{k_{B}}{h}+\frac{\Delta S^{\ddagger}}{R}$

\section{Statistical analysis}

Chemical determinations were made in triplicates and the coefficients of variation were lower than $5 \%$. All results are expressed as mean values. All data were analyzed using Microsoft Excel $2007{ }^{\circledR}$ and QtiPlot 0.9.8.9 ${ }^{\circledR}$.

\section{Results and discussion}

Proximate composition. The results of the pellets proximate composition expressed in $\mathrm{g} / 100 \mathrm{~g}$ of sample $\pm \mathrm{SD}$ were: humidity (10.66 \pm 0.067$)$, ash $(5.34 \pm 0.040)$, fiber $(0.28 \pm 0.015)$, ether extract $(3.35 \pm 0.007)$, protein $(7.69 \pm 0.046)$, and soluble carbohydrates (72.68). These results represent the mean of 3 repetitions with their SD. Harper (1989) and Wang et al. (2008) reported humidity values of $10-12 \mathrm{~g} / 100 \mathrm{~g}$ of sample for the pellets' optimal expansion. The samples analyzed were found to be within this interval. The ether extract was similar to the one reported by Wang et al. (2008) for pellets manufactured with a mix of wheat and soy flours $\left(3.19 \mathrm{~g} 100 \mathrm{~g}\right.$ of sample $\left.{ }^{-1}\right)$. This parameter is very important because rancidity due to oxidation can be a deterioration factor in extruded products during distribution and storage (Riaz, 2004). Carbohydrates are the main component in pellets and this is due to the starch present in the wheat flour used for their elaboration (Riaz, 2004).

Microbiological quality. Microbial growth was not observed in the analyzed samples neither at the beginning nor at the end of the study, which might indicate that the pellets were manufactured using best practices. Microbial growth in pellets is not considered a deterioration factor, except when the product humidity is not controlled during storage or distribution stages (Shaviklo et al., 2011; Pérez-Flores et al., 2017).

Peroxide value determination (PV). In general, high temperatures used during extrusion increase the peroxide value (Ilo et al., 2000). This was observed in this research, since the PV [mmol peroxide $\left.\mathrm{kg}^{-1}\right]$ increased in function of time (days) for $\mathrm{A}, \mathrm{B}$, and $\mathrm{C}$ packaging at 25 and $40^{\circ} \mathrm{C}$. These results are in agreement with those reported by Rao \& Artz (1989) for an extruded corn based mixture with soybean oil addition. Those 
authors observed a rapid decomposition of peroxides as a result of the high temperatures used, which affected negatively the PV. In despite of that, Alvarez et al. (1990) observed a decrease in the PV of an extruded meat based product. This could have indicated that the matrix used might have an influence on the formation of peroxides.

On the other hand, Zadernowskl et al. (1999) reported that extrusion processing increased PV in both free fat and bound lipids from oat. Nevertheless, the PV was lower in bounded than in the free fat. According to these authors, the binding of lipids may be an additional factor in the increased shelf life of extruded products.

Shelf life estimation. Although lipid oxidation phenomenon has been studied in many types of foods, little systematic research has been conducted on low-moisture foods recently (Barden, 2014). Consequently, there is a lack of information about lipid oxidation and its influence on shelf life of extruded snacks and cereal-base products. In our research, the lipid oxidation reactions in the samples had a linear adjustment behavior (Table 1) and therefore, the shelf life estimate was made based on this parameter. Rao \& Artz (1989) and Riaz (2004), reported that rancidity can be a spoilage factor in extruded food products.

In Figure 1, it is observed the logarithmic relation between ln $[\mathrm{X} /(1-\mathrm{X})]$ and time (days) values, that simulates lipid oxidation of $3 \mathrm{G}$ snacks stored in different packaging ( $\mathrm{A}, \mathrm{B}$ and $\mathrm{C})$. It presented a good linear adjustment for a first order reaction, this according to its determination coefficient value $\left(\mathrm{R}^{2}\right)$, reported in Table 1 .

Similar orders of reaction have been reported in the literature when studying lipid oxidation in different food matrices such as Californian almonds (Lin et al., 2012), poultry meet added with natural antioxidants (Barretto et al., 2003), and vegetable oils (cotton seed, palm and soy) chemically interesterified (Basturk et al., 2007).

The values of $k\left(\right.$ day $\left.^{-1}\right)$ for oxidation reactions of lipids in $3 \mathrm{G}$ snacks are presented in Table 1. It was observed an increase of reaction speed $(k)$ based on temperature $\left({ }^{\circ} \mathrm{C}\right)$. The same behavior was observed during the determination of kinetic parameters of virgin olive oil under rancidity conditions (Gharby et al., 2016).

The value of $\mathrm{E}_{\mathrm{A}}$ was higher in $3 \mathrm{G}$ snacks stored in package $\mathrm{C}$, with a value of $56.86 \mathrm{~kJ} \mathrm{~mol}^{-1}$, which will indicate that it is necessary a greater amount of thermal energy to start lipid autoxidation reactions, this compared to the stored pellet in packaging $\mathrm{A}$, where such deterioration reactions will happen more easily because a lower $\mathrm{E}_{\mathrm{A}}\left(23.12 \mathrm{~kJ} \mathrm{~mol}^{-1}\right)$ is required. The obtained values of $\mathrm{E}_{\mathrm{A}}$ for packaging $\mathrm{B}$ and $\mathrm{C}$ are similar to the ones reported by Yoshii et al. (1999), for the autoxidation of EPA $\left(53.6 \mathrm{~kJ} \mathrm{~mol}^{-1}\right)$ and DHA $\left(52.1 \mathrm{~kJ} \mathrm{~mol}^{-1}\right)$.

Formation of the first free radical that initiates the autoxidation reaction needs great amounts of energy $\left(\mathrm{E}_{\mathrm{A}}\right.$ around 18 to $146 \mathrm{KJ} / \mathrm{mol}$ ). This energy comes from applying temperature; from natural irradiation; from the action of singlet oxygen; or from other sources. Less energy is required if there are traces of byproducts of lipid oxidation in the media and in the presence of traces of transition metals such as copper, iron or magnesium (McClements \& Decker, 2000; Nawar, 2010). The $\mathrm{E}_{\mathrm{A}}$ values obtained for the autoxidation of lipids in pellets were found to be within this interval (Table 1). The results showed that pellets are more susceptible to deterioration in packaging $\mathrm{A}$ and $\mathrm{B}$, while in packaging $C$ larger activation energy is required which signals a higher degree of protection.

Regarding the entropy of activation results $\left(\Delta S^{\ddagger}\right)$, these were $-208.83,-121.01$ and $-101.23 \mathrm{~J} \mathrm{~K}^{-1} \mathrm{~mol}^{-1}$, for packaging A, B and C

Table 1. Reaction rates, calculated activation enthalpy $\left(\Delta \mathrm{H}^{\ddagger}\right)$, activation entropy $\left(\Delta S^{\ddagger}\right)$, activation energy $\left(\mathrm{E}_{\mathrm{A}}\right)$, shelf life $(\odot)$ for $3 \mathrm{G}$ snack.

\begin{tabular}{|c|c|c|c|c|c|c|c|c|c|c|}
\hline \multirow{2}{*}{ Packaging } & \multicolumn{2}{|c|}{ Reaction rates $(k) /$ day $^{-1}$} & \multicolumn{2}{|c|}{$\mathrm{R}^{2}$} & \multirow{2}{*}{$\Delta \mathrm{H}^{\ddagger} / \mathrm{kJ} \mathrm{mol}^{-1}$} & \multirow{2}{*}{$\Delta \mathrm{S}^{\ddagger} / \mathrm{J} \mathrm{K}^{-1} \mathrm{~mol}^{-1}$} & \multirow{2}{*}{$\mathrm{E}_{\mathrm{A}} / \mathrm{kJ} \mathrm{mol}^{-1}$} & \multirow{2}{*}{$\mathrm{Q}_{10}$} & \multicolumn{2}{|c|}{$\odot /$ years } \\
\hline & $25^{\circ} \mathrm{C}$ & $40^{\circ} \mathrm{C}$ & $25^{\circ} \mathrm{C}$ & $40^{\circ} \mathrm{C}$ & & & & & $25^{\circ} \mathrm{C}$ & $40^{\circ} \mathrm{C}$ \\
\hline $\mathrm{A}$ & 0.0190 & 0.0298 & 0.9827 & 0.9391 & 20.58 & -208.83 & 23.12 & 1.33 & 0.6040 & 0.3754 \\
\hline B & 0.0123 & 0.0326 & 0.7952 & 0.9688 & 47.85 & -121.01 & 50.39 & 1.88 & 0.9297 & 0.3586 \\
\hline $\mathrm{C}$ & 0.0098 & 0.0293 & 0.8827 & 0.9652 & 54.32 & -101.23 & 56.86 & 2.04 & 1.1175 & 0.3868 \\
\hline
\end{tabular}

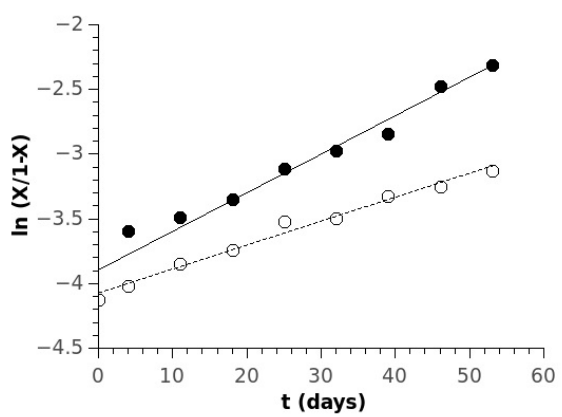

(A)

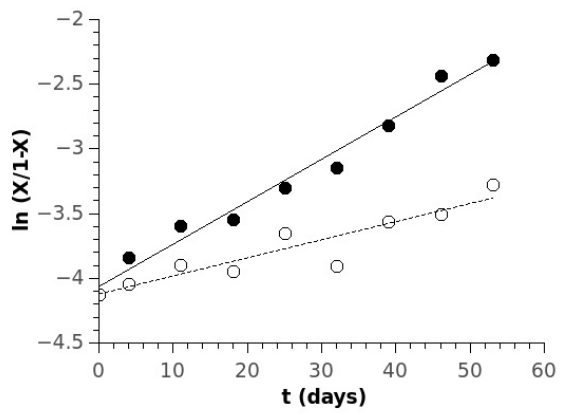

(B)

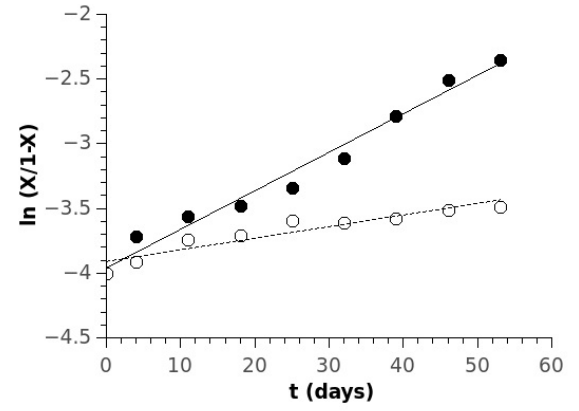

(C)

Figure 1. (०) Stored pellets kinetics at $25^{\circ} \mathrm{C}$ and $(\bullet)$ stored pellets kinetics at $40{ }^{\circ} \mathrm{C}$, contained in three different types of packaging: $(\mathrm{A})$ high density polyethylene (HDPE); (B) polypropylene laminated sack covered with Kraft paper; (C) polypropylene laminated sack covered with HDPE. 
respectively. A negative value indicates that activated complexes are more ordered or that they have lost freedom degrees of reactant molecules. Therefore, there is a lower probability of the activated complex for lipids oxidation, thence, it will happen at a slower rate (Avery, 1974; Farhoosh et al., 2008).

In relation to $Q_{10}$ value, it is observed that it has increased from 1.33 in packaging $\mathrm{A}$ to 2.04 in packaging $\mathrm{C}$. In general, a higher value of $Q_{10}$ means that a lower temperature change is necessary to induce a change in lipids oxidation speed present in $3 \mathrm{G}$ snacks (Labuza, 1984; Farhoosh et al., 2008). This is correlated to the shelf life of the product, packaging $\mathrm{C}$ gives a better protection to 3G snacks stored at $25^{\circ} \mathrm{C}$ and $40^{\circ} \mathrm{C}$, of 1.1175 and 0.3868 years, respectively, compared to packaging $\mathrm{A}$ and $\mathrm{B}$ (Table 1 ). The value of $Q_{10}$ of the $3 G$ snack stored in packaging $C$ is similar to the one reported by Farhoosh et al. (2008) for the oxidation of olive oil (2.08), which can lead to think they have similar oxidation phenomena. It is important to mention that Taoukis \& Labuza (2000), state that products of low humidity have $Q_{10}$ values in a range of 1.5 and 10 , as it was determined in $3 \mathrm{G}$ snacks.

To estimate shelf life, it was used a switching value of $5 \mathrm{mmol}$ peroxide $\mathrm{kg} \mathrm{oil}^{-1}\left(10 \mathrm{meq} \mathrm{O}_{2} \mathrm{~kg}^{-1}\right)$, in as much as a low peroxide value $\left(<10\right.$ meq $\left.\mathrm{O}_{2} \mathrm{~kg}^{-1}\right)$ indicates a non-rancid fat, according to Smith \& Smith (2011). The shelf life values obtained show that the most adequate packaging to store pellets and preserve their properties at $25^{\circ} \mathrm{C}$ is packaging $\mathrm{C}$, followed by $\mathrm{B}$ and $\mathrm{A}$. These results are attributed to the permeability towards $\mathrm{O}_{2}$ present in the materials that constitute the test packaging. Massey (2003) reported permeability values for $\mathrm{O}_{2}\left(\mathrm{O}_{2} \times 10^{11} \mathrm{~mL} \mathrm{~cm} \mathrm{~cm}{ }^{-2} \mathrm{~s}^{-1} \mathrm{~cm} \mathrm{Hg}^{-1}\right)$ between 5 and 17 for HDPE, and between 9 and 16 for PP at $23^{\circ} \mathrm{C}$ and $0 \% \mathrm{HR}$.

Kinetic parameters are useful to predict lipid oxidation behavior during heat treatment, storage and distribution (Tan et al., 2001a). Many factors could affect those parameters, such as, e.g., kind (free or bounded lipids) and content of fat, fatty acid composition, presence of antioxidants and prooxidants, metal ions and the biological variability of the raw material (Zadernowskl et al., 1999; Symoniuk et al., 2017). Regarding to the samples studied in this research, besides the factors mentioned above, it is fundamental to consider the packaging material as well as temperature to reduce the deterioration reactions related to lipid oxidation.

\section{Conclusion}

The main deterioration factor in pellets was rancidity. The kinetic parameters calculated according to the proposed model allowed for the estimation of the pellets shelf life. The materials that constitute the laminated packaging C (HDPE $+\mathrm{PP}$ ) and their permeability properties favor the preservation of the food product by hindering the migration of water vapor and oxygen. The addition of an aluminum film to the structure of packaging $\mathrm{C}$ and the control of storage conditions (temperature and relative humidity) contribute to the extension of their shelf life. Finally, the estimation of different kinetic parameters such as $\mathrm{E}_{\mathrm{A}}, \Delta \mathrm{H}^{\ddagger}$ and $\Delta \mathrm{S}^{\ddagger}$ of activation, might be an important factor to predict the thermal stability of $3 \mathrm{G}$ snacks, as well as the most suitable type of packaging to avoid deterioration phenomena.

\section{References}

Alvarez, V. B., Smith, D. M., Morgan, R. G., \& Booren, A. M. (1990). Restructuring of mechanically deboned chicken and nonmeat binders in a twin-screw extruder. Journal of Food Science, 55(4), 942-946. http://dx.doi.org/10.1111/j.1365-2621.1990.tb01570.x.

Association of Official Analytical Chemists - AOAC. (1990). Official methods of analysis (15th ed.). Rockville: AOAC.

Avery, H. E. (1974). Theory of reaction rates. In H. E. Avery (Ed.), Basic reactions kinetics and mechanisms (chap. 5, pp. 59-70). London: Macmillan Education. http://dx.doi.org/10.1007/978-1-349-15520-0_5.

Bárcenas-Serrano, J. C. I., Pérez-Flores, J. G., Castañeda-Ovando, A., Jaimez-Ordaz, J., \& Contreras-López, E. (2015). Shelf life estimation of extruded snacks expanded by frying and by using hot air stored in polypropylene and metallized polypropylene packaging. In $\mathrm{H}$. S. Santos García, G. P. García Galindo \& G. V. Nevárez-Moorillón (Eds.), Advances in science, biotechnology and safety of foods (chap. 34, pp. 245-252). México: Asociación Mexicana de Ciencia de los Alimentos.

Barden, L. M. (2014). Understanding lipid oxidation in low-moisture food (Doctoral dissertation). Retrieved from http://scholarworks. umass.edu/dissertations_2/155

Barretto, A. C. S., Ida, E. I., Silva, R. S. F., Torres, E. A. F. S., \& Shimokomaki, M. (2003). Empirical models for describing poultry meat lipid oxidation inhibition by natural antioxidants. Journal of Food Composition and Analysis, 16(5), 587-594. http://dx.doi. org/10.1016/S0889-1575(03)00023-1.

Basturk, A., Javidipour, I., \& Boyaci, I. H. (2007). Oxidative stability of natural and chemically interesterified cottonseed, palm and soybean oils. Journal of Food Lipids, 14(2), 170-188. http://dx.doi. org/10.1111/j.1745-4522.2007.00078.x.

Farhoosh, R., Niazmand, R., Rezaei, M., \& Sarabi, M. (2008). Kinetic parameter determination of vegetable oil oxidation under Rancimat test conditions. European Journal of Lipid Science and Technology, 110(6), 587-592. http://dx.doi.org/10.1002/ejlt.200800004.

Gharby, S., Harhar, H., Mamouni, R., Matthäus, B., Ait Addi, E. H., \& Charrouf, Z. (2016). Chemical characterization and Kinetic parameter determination under Rancimat test conditions of four monovarietal virgin olive oils grown in Morocco. OCL, 23(4), A401. http://dx.doi.org/10.1051/ocl/2016014.

Harper, J. M. (1989). Food extruders and their applications. In C. Mercier, P. Linko \& J. M. Harper (Eds.), Extrusion cooking (chap. 1, pp. 1-16). St. Paul: American Association of Cereal Chemists.

Hornero, M. D., Antonio Pérez, G. A., \& Mínguez, M. M. I. (2001). A rapid spectrophotometric method for the determination of peroxide value in food lipids with high carotenoid content. Journal of the American Oil Chemists' Society, 78(11), 1151-1155.

Huber, G. (2001). Snack foods from cooking extruders. In E. W. Lusas \& L. W. Rooney (Eds.), Snack foods processing (chap. 10, pp. 315-368). Boca Raton: CRC Press. http://dx.doi.org/10.1201/9781420012545. ch12.

Huber, G. R., \& Rokey, G. J. (1990). Extruded snacks. In R. G. Booth (Ed.), Snack food (chap. 7, pp. 107-138). An AVI book. New York: Van Nostrand Reinhold. http://dx.doi.org/10.1007/978-1-4613-1477-6_7.

Ilo, S., Schoenlechner, R., \& Berghofe, E. (2000). Role of lipids in the extrusion cooking processes. Grasas y Aceites, 51(1-2), 97-110. http://dx.doi.org/10.3989/gya.2000.v51.i1-2.410.

International Food Information Service - IFIS. (2009). Snack foods. In International Food Information Service - IFIS. Dictionary of Food Science \& Technology (2nd ed.). Oxford: Wiley-Blackwell. 
Labuza, T. P. (1984). Application of chemical kinetics to deterioration of foods. Journal of Chemical Education, 61(4), 348. http://dx.doi. org/10.1021/ed061p348.

Lin, X., Wu, J., Zhu, R., Chen, P., Huang, G., Li, Y., Ye, N., Huang, B., Lai, Y., Zhang, H., Lin, W., Lin, J., Wang, Z., Zhang, H., \& Ruan, R. (2012). California almond shelf life: lipid deterioration during storage. Journal of Food Science, 77(6), C583-C593. http://dx.doi. org/10.1111/j.1750-3841.2012.02706.x. PMid:22582861.

Maskan, M., \& Altan, A. (2011). Advances in food extrusion technology. Boca Raton: CRC Press. http://dx.doi.org/10.1201/b11286.

Massey, L. K. (2003). Permeability properties of plastics and elastomers. A guide to packaging and barrier materials (2nd ed., pp. 49). New York: Plastics Design Library.

McClements, D. J., \& Decker, E. A. (2000). Lipid oxidation in oil-in-water emulsions: impact of molecular environment on chemical reactions in heterogeneous food systems. Journal of Food Science, 65(8), 12701282. https://doi.org/10.1111/j.1365-2621.2000.tb10596.x.

Nawar, W. W. (2010). Lípidos. In O. R. Fennema (Ed.), Química de los alimentos (3rd ed., pp. 270-376). España: Acribia.

Özilgen, S., \& Özilgen, M. (1990). Kinetic model of lipid oxidation in foods. Journal of Food Science, 55(2), 498-498. http://dx.doi. org/10.1111/j.1365-2621.1990.tb06795.x.

Pérez-Flores, J. G., Jaimez-Ordaz, J., Añorve-Morga, J., GonzálezOlivares, L. G., Castañeda-Ovando, A., \& Contreras-López, E. (2017). Influence of water sorption phenomena on the shelf life of third generation snacks. Journal of Food Process Engineering, 40(1), 1-7. https://doi.org/10.1111/jfpe.12328.

Rao, S. K., \& Artz, W. E. (1989). Effect of extrusion on lipid oxidation. Journal of Food Science, 54(6), 1580-1583. http://dx.doi. org/10.1111/j.1365-2621.1989.tb05164.x.

Riaz, M. N. (2004). Extrusores en las aplicaciones de alimentos. Zaragoza: Acribia.

Robertson, G. L. (2012). Food packaging and shelf life. In G. L. Robertson (Ed.), Food packaging and shelf life, a practical guide (chap. 1, pp. 1-16). New York: CRC Press.

Shaviklo, G. R., Thorkelsson, G., Rafipour, F., \& Sigurgisladottir, S. (2011). Quality and storage stability of extruded puffed corn-fish snacks during 6-month storage at ambient temperature. Journal of the Science of Food and Agriculture, 91(5), 886-893. http://dx.doi. org/10.1002/jsfa.4261. PMid:21384356.

Smith, S. B., \& Smith, D. R. (2011). Analysis of rendered fats. In L. M. Nollet \& F. Toldrá (Eds.), Handbook of analysis of edible animal byproducts (chap. 3, pp. 37-42). New York: CRC Press. http://dx.doi. org/10.1201/b10785-5.

Symoniuk, E., Ratusz, K., \& Krygier, K. (2017). Kinetics parameters of refined and cold-pressed rapeseed oils after oxidation by Rancimat. Italian Journal of Food Science, 29, 276-287.

Tan, C. P., Man, Y. C., Jinap, S., \& Yusoff, M. S. A. (2001a). Effects of microwave heating on changes in chemical and thermal properties of vegetable oils. Journal of the American Chemical Society, 78, 1227-1232.

Taoukis, P., \& Labuza, T. P. (2000). Resumen: integración conceptual. In R. O. Fenema (Ed.), Química de los alimentos (chap. 17, pp. 12011236). Zaragoza: Editorial Acribia.

Tan, C. P., Che Man, Y. B., Selamat, J., \& Yusoff, M. S. A. (2001b). Application of Arrhenius kinetics to evaluate oxidative stability in vegetable oils by isothermal differential scanning calorimetry. Journal of the American Oil Chemists' Society, 78(11), 1133-1138. http://dx.doi.org/10.1007/s11746-001-0401-1.

Waletzko, P., \& Labuza, T. P. (1976). Accelerated shelf-life testing of an intermediate moisture food in air and in an oxygen-free atmosphere. Journal of Food Science, 41(6), 1338-1344. http://dx.doi. org/10.1111/j.1365-2621.1976.tb01166.x.

Wang, S. H., Nascimento, T. P., Batista, G. S., Meneses, S. P., \& Ascheri, J. L. R. (2008). Pellets de trigo e soja produzidos por extrusão. Ciência e Tecnologia de Alimentos, 28(3), 629-634. http://dx.doi.org/10.1590/ S0101-20612008000300019.

Yoshii, H., Furuta, T., Itoh, T., Yoshimura, K., Misawa, Y., Hata, N., Kobayashi, H., Linko, Y.-Y., \& Linko, P. (1999). Kinetic analysis of the autoxidation of ethyl eicosapentaenoate at different oxygen levels. Bioscience, Biotechnology, and Biochemistry, 63(4), 662-665. http://dx.doi.org/10.1271/bbb.63.662. PMid:27389101.

Zadernowskl, R., Nowak-Polakowska, H., \& Rashed, A. A. (1999). The influence of heat treatment on the activity of lipo- and hydrophilic components of oat grain. Journal of Food Processing and Preservation, 23(3), 177-191. http://dx.doi.org/10.1111/j.1745-4549.1999.tb00378.x.

Abbreviations

\begin{tabular}{|c|c|c|c|}
\hline$h$ & Planck's constant $\left(6.6260755 \times 10^{-34} \mathrm{Js}\right)$ & $k_{B}$ & Boltzmann's constant $\left(1.380658 \times 10^{-23} \mathrm{~J} \mathrm{~K}^{-1}\right)$ \\
\hline$k$ & reaction rate $\left(\right.$ days $\left.^{-1}\right)$ & $\mathrm{E}_{\mathrm{A}}$ & activation energy $\left.(\mathrm{kJ} \mathrm{mol})^{-1}\right)$ \\
\hline $\mathrm{R}$ & gas constant $\left(8.314510 \mathrm{~J} \mathrm{~mol}^{-1} \mathrm{~K}^{-1}\right)$ & $\mathrm{A}$ & pre-exponential factor $\left(\right.$ days $\left.^{-1}\right)$ \\
\hline $\mathrm{T}$ & absolute temperature $(\mathrm{K})$ & $\Delta \mathrm{H}^{\ddagger}$ & activation enthalpy $\left(\mathrm{kJ} \mathrm{mol}^{-1}\right)$ \\
\hline $\mathrm{t}$ & time (days) & $\Delta \mathrm{S}^{\ddagger}$ & activation entropy $\left(\mathrm{J} \mathrm{K}^{-1} \mathrm{~mol}^{-1}\right)$ \\
\hline$\odot$ & shelf life (years) & & \\
\hline
\end{tabular}

